\title{
The vitamin and mineral status of sheep in West Asia
}

\author{
CL. White 1, T Treacher 2, F Bahhady 2 \\ 1CSIRO Division of Animal Production, Private Bag, PO Wembley, Western Australia 6014, Australia ; \\ 2International Centre for Agricultural Research in the Dry Areas, PO Box 5466, Aleppo, Syria
}

There are 355 million sheep and goats in West Asia and North Africa and they contribute a substantial proportion to total farm income. Most sheep are raised as an adjunct to crop production and are fed on crop residues and grain. Despite some reports of possible white muscle disease and enzootic ataxia in lambs in parts of Turkey, there are no published data on the macro-mineral and micro-nutrient status of sheep in this region.

The aim of the work was to provide quantitative information on the mineral (macro and micro) and vitamin $\left(A, E\right.$ and $B_{12}$ ) status of lactating Awassi ewes in the major sheep-producing areas of Syria, Jordan and Turkey. Blood and feed samples were taken from flocks at 18 sites during February 1994.

There was a high incidence of hypovitaminosis $E$, hypocalcaemia and hypophosphataemia in the ewes. Two flocks in Turkey showed evidence of Se deficiency, two in Syria were $\mathrm{Cu}$ deficient and one was $\mathrm{Zn}$ deficient. Diets based on cereal grain were deficient in $\mathrm{Na}$ (e.g. barley $<0.04 \% \mathrm{Na}$ ) and lambs fed on these diets exhibited pica (chewing mud walls), a typical manifestation of $\mathrm{Na}$ deficiency. The results showed that deficiencies of macro- and micro-nutrients were common and suggest that strategic use of appropriately formulated mineral supplements may be a cost-effective means of increasing animal productivity.

\begin{tabular}{lccc}
\hline Plasma concentration & Median & Range & $\begin{array}{c}\text { Number of deficient flocks } \\
\text { (critical minimum } \\
\text { value shown in brackets) }\end{array}$ \\
\hline Retinol $(\mathrm{mg} / \mathrm{l})$ & 0.59 & $0.42-0.87$ & $0(0.2 \mathrm{mg} / \mathrm{l})$ \\
$\alpha-$ Tocopherol $(\mathrm{mg} / \mathrm{l})$ & 1.29 & $0.29-3.01$ & $5(1.0 \mathrm{mg} / \mathrm{l})$ \\
Vitamin $\mathrm{B}_{12}(\mu \mathrm{g} / \mathrm{l})$ & 2.56 & $0.62-4.09$ & $0(0.3 \mu \mathrm{g} / \mathrm{l})$ \\
Calcium $(\mathrm{mM})$ & 2.39 & $1.27-2.77$ & $7(2.4 \mathrm{mM})$ \\
Magnesium $(\mathrm{mM})$ & 1.08 & $0.69-1.38$ & $1(0.82 \mathrm{mM})$ \\
Phosphorus $(\mathrm{mM})$ & 1.74 & $1.05-3.61$ & $6(1.61 \mathrm{mM})$ \\
Copper $(\mathrm{mg} / \mathrm{l})$ & 1.04 & $0.19-1.29$ & $2(0.3 \mathrm{mg} / \mathrm{l})$ \\
Selenium $($ whole blood, mg/l) & 0.21 & $0.03-0.41$ & $2(0.05 \mathrm{mg} / \mathrm{l})$ \\
Zinc $(\mathrm{mg} / \mathrm{l})$ & 0.77 & $0.59-1.03$ & $1(0.6 \mathrm{mg} / \mathrm{l})$ \\
\hline
\end{tabular}

